\title{
Community-Based Natural Resources Management and Rural Development in Nigeria: A Theoretical Review
}

\author{
Rosemary I. Eneji and S. O. Ering \\ Department of Sociology \\ Faculty of the Social Sciences \\ University of Calabar \\ Nigeria
}

\begin{abstract}
Nigeria experiences many challenges such as poor economic growth, severe depletion of natural resources in densely populated areas, frequent weather changes and human diseases like malaria and AIDS. Communitybased natural resources management (CBNRM) is the management of land and natural resources which is relevant to, and has the potential to provide solutions to some of the problems in rural settlements, where majority of people live with, and depend on, these resources. Community-based natural resources management should lead to an improvement in the status of the resources and the livelihoods of those living with and managing them. This implies the sustainable use of the resources for the benefit of people. The main thrust of this review is to critically assess CBNRMand rural development based on some sociological theories. The government, concerned organizations and individuals have roles to play in the sustainable development of natural resources and their translation into practical development in rural areas. However, there is need to transition from preservationist and state-driven strategies of natural resources management to a collaborative management approach with full involvement of the host communities.
\end{abstract}

Keywords: Community, natural resources, rural society, development.

\section{Introduction}

Rural communities in developing countries world-wide have relied on natural resources to support daily livelihoods, thus conserving biodiversity would reduce rural poverty. Natural resource management in the developing/rural economy focuses on the life supporting capacity of these resources. The management of natural resources is complex because its scope extends to ecological and hydrological cycles, as well as animals and plants. From the outcome of the United Nations Conference for the Environment and Development (UNCED) in Rio de Janeiro in 1992, "top down approach is a key to rural development. Community-based natural resource management has conservation objectives for the economic and social benefits of the rural communities. Natural resources in the rural areas are inherited from one generation to another because of communal living and belief that they have a putative ancestor called 'Father'.

Community-based natural resource management involves community empowerment and participation in decisionmaking and management activities for natural resources and the decentralization of ownership to the communities and local institutions integrally involved in the resource use (Armitage, 2005; Gandiwa et al., 2013; Turner, 2004). It is therefore considered that community-based natural resources management is a broad concept used to describe the approach undertaken when designing a natural resources management project rather than a type of project in itself.

Historically, most land and the associated resources were seen as the property of the government. This perception was inherited from colonial times, when fees and fines prevented the native people from making consumptive use of games, trees and other resources on the land around the village. Rural people in Nigeria are dependent on natural resources such as firewood for cooking and poles and grass to make their thatch houses but have tended to over-exploit them in recent times. Further, they are apathetic to the state of their surrounding environment. Many rural people have detailed knowledge of the land around their homes and the resources it contains. On the other hand, governments are dependent on formal, costly surveys, fact-finding missions and inventories to get all their information, which is particularly lacking in remote, sparsely populated areas. 
Natural resources management and conservation demonstrates a preference for programmes and strategies that alienate rural communities from the resources on which they subsist. These resource conservation strategies, mainly characterized by top-down approaches, generated conflicts between rural communities and conservation agencies because the indigenous rural economies were directly linked to the same natural resources base. These strategies led to resentment and apathy by rural communities towards any conservation attempt and this resulted in conservation agencies presiding over declining natural resources. This situation required a transition from preservationist and state-driven strategies of natural resources management to a collaborative management approach with the same rural communities. This shift in conservation paradigm to a mere integrated approach recognized the need to promote involvement and empowerment of rural communities by linking their economic and social development to natural resources management programmes leading to development.

\section{Community and natural resources}

Community-based management of natural resources has become a topical issue of concern to most scholars in Nigeria and the world at large because of its importance to community development. Community-based natural resources management combines conservation objectives with the generation of economic benefits for rural communities. When a local people's quality of life is enhanced, the efforts and commitment to ensure the future well-being of their resources is also enhanced. Community-based management of natural resources is also based on the reorganization or restructuring of authority to create a system of co-responsibility between institutions of governance at the central, regional and local levels (Susskind et al., 1999). The United Nations advocates community-based natural resources management in the conservation of biodiversity and the combat of desertification.

Community-based management of natural resources is based particularly on advocacy by non-governmental organizations working with local groups and communities on the one hand and national and international organizations on the other, to build and extend new versions of environmental and social advocacy linking social justice and environmental management agenda with both direct and indirect benefits. Community-based management of natural resources has raised new challenges as concept of community, territory and conservation are worked into politically varied plans and programmes in disparate sites.

\section{Rural infrastructure and community participation in development}

Majority of Nigerians are rural dwellers. Though lack of data make knowledge of actual rural-urban population distribution inexact, unadjusted projections still show that Nigerians predominantly live in rural areas characterized by severe material poverty and alarming lack or decay of infrastructure, arising from long period of neglect by policy makers. The central place of infrastructure in development efforts need not be overemphasized. Indeed, rural infrastructures constitute the substance of rural welfare and progress. Idachaba (1985) suggested that efforts to raise rural welfare must necessarily go beyond the traditional and limited approach of raising per capita income through agricultural development project to the provision of rural basic needs. These needs include health and medical facilities, rural transportation facilities, electricity, pipe-borne water and schools. Beyond their roles as producers and sources of food and materials for urban dwellers, the rural dwellers must be recognized, appreciated and entitled to good things of life like their urban counterparts.

Successive governments in Nigeria recognized this fact, even if they did little to address it. Previously, there was a tendency to measure economic performance based on such aggregates as the GDP, etc. However, such things as the availability of drinking water, housing units, medical facilities, educational facilities and good roads provide a good measure of development (Guideline for Fourth National Development Plan, 1981-85:23). Rural infrastructures are very critical for rural development and other equally important programmes. The national accelerated food production programme, the operation feed the nation, the green revolution and other governmental development projects have had limited success in many areas because of very poor infra-structural support. In recognition of this, the federal and state governments have variously made commitments in this direction. A good example is found in the Third National Development Plan where the government declared that "efforts will be made to enhance the quality of life in the rural areas through the provision of basic social amenities such as health centres, pipe-borne water, feeder roads and electricity". By virtue of the provisions of the 1979 and 1999 constitutions of the Federal Republic of Nigeria, most aspects of the rural infrastructures are on the concurrent legislative list, in which case, they are joint Federal, State and Local Government responsibility. 
In the context of rural infrastructural development, community participation is very relevant. Community participation refers to an active process whereby beneficiaries influence the direction and execution of development projects rather than merely receiving a share of project benefit (Pual, in Banberger, 1986). Local participation is seen as one of the solutions to project sustainability. Community participation approach does not only improve the success of the infrastructure but also makes infrastructure more efficient and effective (McGee, 2002).

Since the 1990's, multilateral agencies such as the World Bank placed greater emphasis on stakeholders participation as a way to ensure development sustainability (Gonzales, 1998). It is now regarded as a critical component that could promote the chances of development initiatives being sustainable through community capacity building and empowerment (Brett, 2003; Bigdon and Karf, 2002; Botchway, 2001). Empowerment in this context means giving people who are marginalized, vulnerable and excluded from development, the ability to be self-reliant to manage their own resources. It is believed that participation would lead to empowerment through capacity building skills and training (Lyons et al., 2001).

Evidence of the performance of community participation approach is scant, but available records suggest that practitioners may be over-optimistic about the benefits of the approach (Mannsuri and Rao, 2004a). The empirical literature on community participation acknowledges that there may be large gaps between the idealized representation of the concept and non-profit organizations' experiences with the approach. Given that community participatory processes are known to be expensive, demanding and time-intensive, it is vital to better understand the effect of this approach on the sustainability of community development projects. Mansuri and Rao (2004) conclude that little is known of the effects of community participation on community-based projects and that robust evidence regarding the influence of community participation was required urgently.

\section{Employment generation and poverty reduction through community-based-natural resources}

The rate of unemployment in Nigeria is currently alarming as it affects professional, skilled and unskilled labour. The rate was $19 \%$ in 1999, 10\% in 2003 and $18.6 \%$ in 2006 (CBN, 2006). In recent times, the incidence of unemployment in Nigeria had been deep and widespread, cutting across age groups, educational strata and geographical entities.

Creating jobs is a keystone of any economic program. Politically, employment opportunities give the population a stake in a peacefulsociety by providing young men and women with alternative to violence. Economically employment provides income to poor families, revive domestic demand for goods and services, and stimulates overall growth. Socially, employment is a function of the extent to which the political-social-economic system is able to harness available resources to meet human needs. The level of employment generated is not fixed according to any universal laws of economics but depends on an explicit policy on which the system is based. Changing those values and policies changes the system availability of employment. There is ample scope for increasing employment generation or opportunities in every country through a judicious application of policies and programmes. The problem of employment is closely interlinked with the eradication or reduction of poverty. The World Bank defines poverty as hunger, lack of shelter, being sick and unable to see a doctor, inability to go to school, illiteracy, joblessness, fear of future, living one day at a time, lack of access to clean water, powerlessness and lack of representation and freedom. Poverty alleviation refers to the modes being adopted to eradicate poverty in the society. However, like most things, poverty alleviation is not a simple act as simple economic growth will not reduce or alleviate poverty unless such growth is inclusive of all individuals in the economy. For much of history, poverty was considered largely unavoidable as traditional modes of production were insufficient to give an entire population a comfortable standard of living. Poverty creates an imbalance in population explosion, unemployment, and childlabour and crime incidence. Poverty can be ascribed to inadequate access to employment opportunities, physical assets, markets, destruction of natural resources, lack of power to participate in design of development programmes, etc. Aku et al. (1997) suggested that a general loss of confidence in a society stricken by poverty renders government policies ineffective.

To reduce poverty, economic liberation extending property rights protection to the poor is key. The right to land, the largest asset for most societies is vital to economic freedom. The World Bank considers that increased land rights is the key to reducing poverty since they greatly increase poor people's wealth, in some cases doubling it. Good infrastructure, such as road and information networks, helps markets reform to work, just as cell phone technology brings the market to the poor or rural sections. 
Such technology also helps bring economic freedom by making financial services accessible to the poor. Economic growth has the indirect potential to alleviate or reduce poverty because of the simultaneous increase in employment opportunities and increased labour productivity. Availability of employment opportunities is just as important as the increased income and access to basic needs. Microloans are one of the most famous as exemplified by the Grameen Bank in Bangladesh. The idea is to loan small amounts of money to farmers or villages so these people can obtain the things they need to increase their economic rewards. Empowering women, increasing the supply of basic needs - food and good agricultural technologies such as nitrogen fertilizers, pesticide, etc, and removing constraints to government services will assist in reducing poverty.

\section{Theoretical framework}

The following two theories will be used to provide a framework for this review of community-based management of natural resources:

\section{Structural functionalism}

This theory sees society as a single interconnected (interdependent) social system (Charles, 2005), each segment of which performs a definite function. This basic feature is the interaction of its components (parts) and the function integration of the system from the interdependence of the parts. Structural functionalism attributes to a social system that is characteristic of communities - agreement, cohesion, solidarity and consensus. It assumes that the structure (parts) of a system are independent and function together (in harmony) for the maintenance of the system. Thus, functionalism considers any social factor (phenomenon), occurrence or change as necessary (function) to the survival (existence/persistence) of the system. The society persists on the principle of functional interaction (Ottong, 2004).Thus, the community is part and parcel of the social system. Communities constantly strive to achieve their goals of preservation (including of natural resources) and development sometimes by engaging in activities that could cause disequilibrium and disorganization in the social system. Therefore, for there to be harmony in the social system, the community must be involved in development activities as part of community development and preservation effort.

Structural functionalism helps community members understand how collective means can help till social needs. It also helps to explain to the communities and individuals a number of activities required to ensure that certain needs are fulfilled to sustain social life and help a society/community to develop.

\section{Interest game theory}

This theory, also called interactive decision theory" strategically studies mathematical models of conflict and cooperation between intelligent, rational decision-makers. The elements of this theory are the players of the game, the information and the actions available to each player at each decision point, and the payoffs for each outcome. Game theorists characteristically use these elements and a solution concept of their choosing to deduce a set of equilibrium strategies for each player. Thus, when these strategies are employed, no player can profit by unilaterally deviating from the strategy. These equilibrium strategies determine equilibrium to the game - a stable state in which either one outcome occurs or a set of outcome occurs with known probability. The theory suggests that bargaining is likely to lead to winners emerging mostly through collaboration rather than cheating each other. Game theory is based on rationality. And in traditional economic models, rationality is the maximization of one's own payoff. Therefore, in every situation, one will always act to gain as much as possible, regardless of how that affects others. In the context of this review, the "Game" are the natural resources, the players are the external organizations, government or forces and the community, the information and the decision available to each player at each decision point and the payoffs for each outcome refers to the type of natural resources and every information on each resource and how it is to be managed at every given point. The payoff refers to the benefit due each player. Thus, each player, whether government, organization or community, through collaboration will likely emerge a winner. Rather than cheating each other, the players can deduce a set of equilibrium where they will benefit equally without cheating. Since the theory is based on rationality in every situation, the community will always act to gain as much as possible, regardless of how it affects other players. TheGame theory helps community to analyze possible outcomes, identify paths to the outcomes and choose the actions that result in the best outcome as it concerns their natural resources development. It is also useful to understand conflicts that occur within the community; the theory can lead to the best rational results which can maximize benefits for all community members in a community. Game theory is also relevant in addressing rural planning issue. 
More work is needed to ensure that analytical procedures are effectively applied in a community forum. Specific issues that need to be addressed include ways to increase participation of key individuals, facilitate understanding and use, and developing procedures that allow the community to become more fully informed about resources management scenarios and their impacts on the physical, environmental and socio-economic health of the community.

\section{(Rural) Development}

Here, we will focus on the following two key developments that contribute to improved wellbeing of the rural people:

\section{Economic development}

Economic development is considered by most people discussing economic relationships with the environment and environmental issues, to be synonymous with modernization, westernization and especially industrialization. Economic development creates the conditions for economic growth and improves quality of life by expanding the capacity of individuals, firms and communities to maximize benefits by lowering transaction costs and responsibly produce and trade valuable goods and services. The gross domestic product (GDP) is an indicator of economic development of a community but it is not enough to use only this indicator to make conclusions on the economic development and therefore the well-being of the inhabitants of the community. This is mainly because GDP cannot measure the development of the leisure time, the condition of the environment, the true ability of people to be free in what they do or say, their confidence in the system of social justice and their opportunity to get education and health care. Economic development isa sustained community effort to improve both the local economy and quality of life by building the area's capacity to adapt to economic change. Ideally, it refers to the sustained, concerted actions of communities and policy-makers that improve the standard of living and economic health of a specific locality. Economic development requires effective collaborative institutions focused on advancing mutual gain for the public and the private sector; it is essential to ensuring economic future.

\section{Infrastructural development}

Facilities that serve communities include mass transit, communication, sewage, water and electric system, plus good roads and bridges. Infrastructure provides the ability to easily transport goods and people; it is expensive, but important to economic development.The development and maintenance of essential public infrastructure are crucial ingredients for sustainable economic growth and poverty reduction. Poor infrastructure is perhaps the most limiting constraint to growth in the developing regions of the world and has proven essential to bringing the rich countries to the current welfare levels. Adequate health, education and efficient water and sanitation services help lay the groundwork for more productive and healthy populations capable of contributing to sustained economic growth. Likewise reliable transport infrastructure is essential for access to public and private services and markets in rural areas. Well-functioning urban transport infrastructure secures good intercity accessibility to jobs and markets and enhances urban productivity and welfare.

\section{Community participation in development}

Community participation refers to individual and collective actions designed to identify and address issue of public concern. It can take many forms - from individual volunteerism to organizational involvement to electoral participation. It can include efforts to directly address an issue, work with others in a community to solve a problem or interact with the institutions of representative democracy. It is the sense of personal responsibility individuals feel to uphold their obligations, as part of any community.

\section{Conclusion}

Community-based management of natural resources and rural development involves collective management by the government and local communities. If communities are given incentives and proper tools for the management of natural resources, they can organize themselves effectively, taking appropriate actions to conserve these resources. Rural areas with community-based natural resources management progrmmes have spontaneously responded to the need for interaction with the natural resources in a way that also ensures their well-being. Through benefits that contribute to their quality of life and the linkages between such benefits and the natural resources base, the community perceives the resources as belonging to them rather than to the conservation authorities. 
Community-based natural resources management shows that the future of conservation lies in the support of the local communities. Government should create awareness for the community and mobilize them through workshops, seminars and other NGOs towards participation in community-based natural resources management. However, for sustainable and effective management, the benefits must outweigh the cost of conservation, since communities are only likely to conserve and manage what they perceive will make a positive contribution to their quality of life.

\section{References}

Aku, P. S., Ibrahim, M. T., Balas, Y. D. (1997). Perspectives on Poverty Alleviation Strategies in Nigeria.In Proceedings of the Nigeria Economic Society Annual Conference on Poverty Alleviation in Nigeria 1997, Ibadan NES, pp 41-54.

Amitage, D. (2005). Adaptive Capacity and Community-based Natural Resources Management. Environmental Management 35:703-715.

Mc Gee, Barry (2002). The Buddy System .ISBN 0-9648530-3-5.

CBN - Central Bank of Nigeria (2006). Annual Report.Corporate Head Office Central Business District P. M. B. 0187 Garki Abuja, Nigeria.

Charles, J. O. (2005). Social Anthropology: Concept, Theory and Ethnography, Lagos: Serenity Ventures.

Idachaba, F.S. (1985). Concepts and strategies of Integrated Rural Development.Lessons from Nigeria (Food Policy Technical Research Paper).

Gandiwa, E., Heitkong, I. M. A., Prins, H. H. T. \&Leevwis, C. (2013).CAMFIRE and Human Wildlife Conflicts in Local Communities Bordering Northern Gonarezhou National Park, Zimbabwe.Ecology and Society 18.

Mansuri, G. and Rao, V. (2004).Driven Development: A Critical Review. Policy Research Working Paper; No 3209, World Bank, Washington, D.C. World Bank.

Ottong, J. (2004). The Study of Sociology; A Conceptual Approach, Calabar: Adonai Publishing Ouse.

Turner, S. (2004). A Crisis in CBNRM?Affirming the Commons in South Africa.20 ${ }^{\text {th }}$ IASCP Conference Oaxaca. 